\title{
Ethnic Remigration from the Former Soviet Union to Finland - Patterns of Ethnic Identity and Acculturation among the Ingrian Finns
}

\author{
EVE KYNTÄJÄ \\ Researcher \\ Aleksanteri Institute, \\ Finnish Centre for Russian and East-European Studies \\ University of Helsinki \\ Helsinki, Finland
}

\begin{abstract}
The aim of this paper is to examine the patterns of psychological acculturation and ethnic identity of Ingrian Finns - the remigrants from the former Soviet Union - in Finland. The article is based on a study that focused on finding out the relationship between objective criteria of ethnic identity (language, nationality, citizenship, religion) and subjective ethnic identity (self-identification, commitment) in a certain social context. The relationship between acculturation attitudes and psychological well-being was also studied. The approach of the study was qualitative, the methods used were in-depth interviews, and participant observation. The sample consisted of 40 adult Ingrian Finns living in Finland and 10 leaders of the Ingrian Association in St. Petersburg and the Ingrian Church. The results suggest that different age groups have different ethnic self-perceptions. Younger remigrants identify themselves mostly as Russians or Estonians depending on which linguistic and social environment they have lived in. Middle-aged Ingrian Finns are dealing with identity conflict: they have problems in identifying themselves ethnically and also difficulties in integrating into the Finnish society.
\end{abstract}

Keywords: ethnic remigration, Ingrian Finns, Soviet Union, remigration policy, ethnic identity, psychological acculturation, integration, age groups, nationality, citizenship, Finland

\section{Introduction}

Finland has traditionally been a relatively homogeneous country without any marked experiences of multiculturalism. According to the Central Population Register there were about 79,600 foreign citizens living in Finland (October 31, 1997), which corresponds to approximately $2 \%$ of the whole Finnish population. The size of the foreign population has tripled during the past five years. The special characteristics of the Finnish foreign population are that the biggest groups of foreign citizens have come from the former Soviet Union making up about one-third of the total foreign population $(27,000)$. There are approximately 9,600 Estonian, 13,800 Russian, and 4,800 Soviet citizens living in Finland. According to the estimate of the Ministry of Labor there are about 17,000 Ingrian Finns, so-called returnees or remigrants, living in Finland currently. The concept Ingrian remigrant refers to citizens of the former Soviet Union who are of Finnish origin. On the basis of their Finnish descendency they were given the right to move to Finland (Aliens Act February 22, 1990, 378/91). Unfortunately there 
is no official statistical information about their citizenship, native language, etc. Ingrian remigrants can be citizens of Russia, Estonia, Ukraine, Uzbekistan or any other country of the former Soviet Union. As Ingrian remigrants have mainly come from Russia and Estonia they would mostly be either Russian or Estonian citizens, but they might also still hold a Soviet passport.

In 1990, when the remigration policy was officially declared, an economic depression started in Finland, which probably affected the social climate and peoples's attitudes. Magdalena Jaakkola's (1993) study describes the trend of change in the Finns' attitudes to refugees and other immigrants between 1987 and 1993. The results show that attitudes have changed considerably in a negative direction and the negative change pertains to all age, gender, education and social groups, supporters of every political party and to both rural and urban areas. The main reason for the negative attitudes was that Finns feel a socioeconomic threat and particularly a fear of unemployment. There has been a marked increase in negative attitudes towards Russian, Estonian, Polish, Turkish, Vietnamese, Chilean, Kurdish, Somalian, and former Yugoslavian immigrants. Estonians were still quite accepted (among the five most "popular" immigrant groups), but, relatively, negative attitudes towards them have also occurred (Jaakkola 1993). Ingrian Finns were very popular in the ethnic hierarchy in Jaakkola's survey, done in 1993, but this could be explained by the romantic attitudes and illusionary images of remigrants, and the fact that Ingrian Finns are anyhow Finns. There was another analogical survey carried out in 1995 by Ismo Söderling. The results (Söderling 1997) show that the attitudes towards immigrants and refugees have worsened between 1993 and 1995 in Finland.

\section{The aim of the study}

The study focused on the patterns of ethnic identity and psychological acculturation of the Ingrian Finns, who have remigrated to Finland in the 1990s. The main goals of the research were to find out the following:

- the meaning of objective criteria (language, nationality, citizenship, religion) of ethnic identity for the subjective ethnic identity (self-identification, commitment) of remigrants

- how the acculturation attitudes and the subjective ethnic identity of Ingrian Finns are affected by the social context of the host society, especially in respect to xenophobia, stereotypes and prejudices that they have possibly experienced in the host society

- the interrelationship between acculturation attitudes and the psychological well-being of the Ingrian Finns in Finland

- the attitudes of the representatives of the Ingrian Association in Russia towards the remigration of Ingrians to Finland (the causes and effects of remigration).

\section{Methods and sample}

The research sample consisted of two research population groups. The first one included 40 adult Ingrian Finns, who had resettled in Finland after the breakdown of the Soviet Union (1991) and had lived in Finland for at least three years. Half of them were from Russia and half from Estonia. All the interviews were conducted either in Russian, Estonian, or Finnish according to the respondents language skills and preferences. The interviewees were found by the socalled snowball sampling method and data collection was carried out in 1994-1995 in Turku. In respect to age, education level, language skills and socioeconomic position the group of respondents was very heterogenous. Some of the main characteristics of the target group are given in the table below: 
Table 1. Main characteristics of the target group.

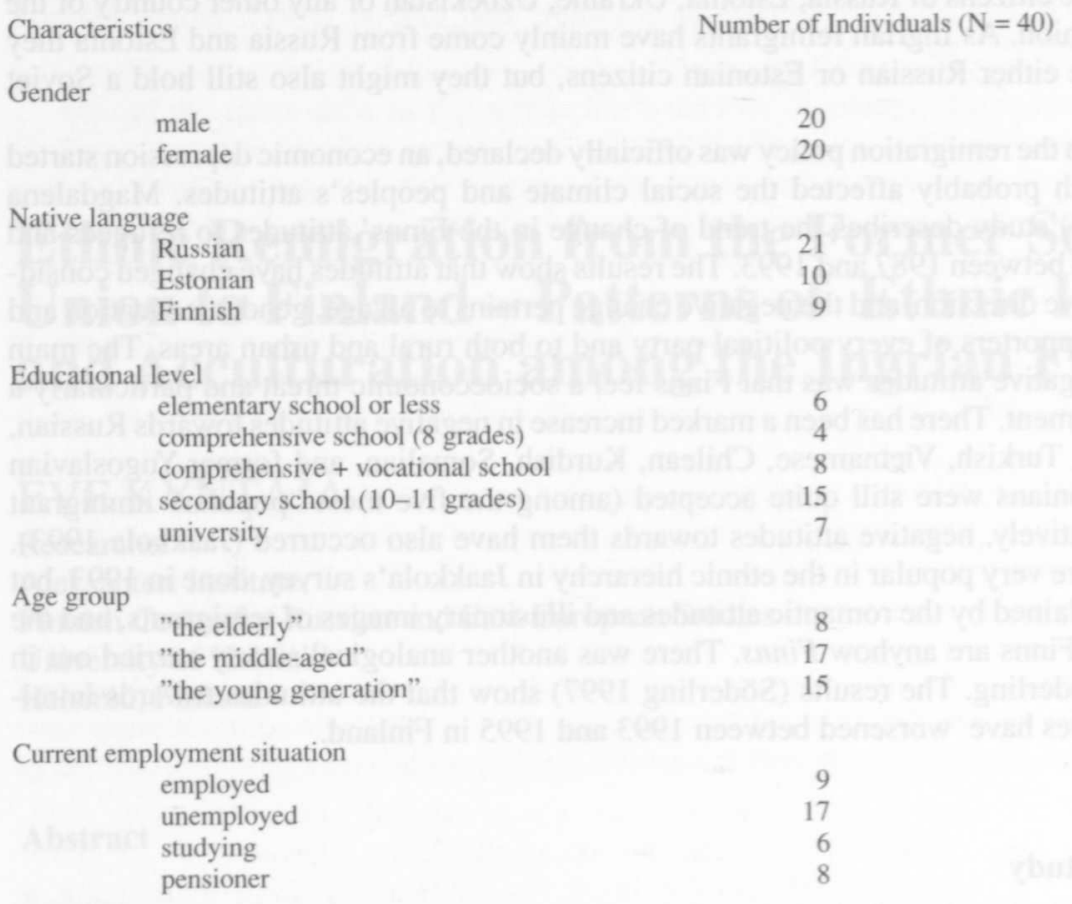

The second part of the target group were the leaders of the Ingrian Association and the Ingrian Church. A total of ten people were interviewed, four women and six men. All the interviews were conducted in November-December 1996 in St. Petersburg either in Russian or in Finnish.

The research method was qualitative, a case-study type, and the methods used were indepth interviews and participant observation. The interviews were semi-structured and based on a framework of open-ended questions. In the analysis of data the grounded theory approach was used. The research topic seemed to require a qualitative approach: there were no patterns identified a piori and the aim of the study was to get new information and understand the meaning of context, actions, and attitudes from the perspective of the respondent. Using inductive analyses the patterns arose from the data providing rich contextual information.

\section{Theoretical framework}

\section{Ethnic identity}

Ethnicity is a concept that has become extremely popular among different disciplines. The maintenance of ethnic identity has become $\approx$ a general issue especially throughout the social sciences. A lot of theories try to define the concept of ethnic identity by emphasizing cultural similarities and differences. It seems, that ethnic identity cannot be studied by examining only objective criteria like native language, nationality, citizenship, religion, etc. Neither can behavioral criteria alone, such as participation in activities within one's own group explain the connotation of ethnic identity.

In the current study, attention is focused on the psychological aspects of ethnic identity, such as subjective identification ("I feel I'm a Finn ...") within the ethnic group. Modern reality gives people the possibility to choose one's identity consciously. Identities could also change in 
different contexts during life phases and contexts. Ethnocultural identity develops throughout a person's lifetime as a result of interactions with members of one's own group and those of surrounding groups (Liebkind 1992, 1996). According to Hutnik (1991) ethnic identity is necessarily an elusive and complex concept. The term often involves a variety of objective and subjective realities. The family's Finnish heritage may be irrelevant to the remigrant adolescent, if it is psychologically important for him/her to be Russian or Estonian. There may be little or no correspondence between the identity which is psychologically important for the individual and the way s/he is perceived by others. For example an Ingrian Finn could define him/herself as a Finn, but the "real Finns" consider him/her as Russian, because of his/her poor Finnish. Self-identification can be used as the single or major indication of ethnic identity but ethnic self-perception alone is not enough. People may use an ethnic label and yet have no feelings for their culture or may even have negative attitudes towards their group (Liebkind 1996).

For different ethnic groups, different features of their culture may contribute to their sense of ethnic identity (Liebkind 1989; Phinney 1990; Weinreich 1989). The variations of subjective ethnic and cultural identity inside the same ethnic group could also be significant, for example for representatives of different generations.

\section{Acculturation}

The concept of acculturation is widely used to refer to the possible changes that groups and individuals undergo when they come into contact with another culture. Group-level acculturation entails economical, technological, social, cultural, and political transformations, while individual-level acculturation, psychological acculturation, entails changes in behavior, values, attitudes and identity (Berry 1990, 1992).

The theory of psychological acculturation developed by Berry $(1990,1992)$ suggests that in culturally plural societies, individuals and groups (especially migrants and refugees) must confront two issues. One pertains to the maintenance and development of one's ethnic distinctiveness in society; one must decide whether one's own cultural identity and customs are of value and should be retained. The other involves the desirability of inter-ethnic contact, deciding whether relations with the larger society are of value and should be sought. By dealing simultaneously with these two issues, four distinct strategies/attitudes can be identified.

Assimilation occurs when an individual wants to "melt" into the dominant group and relinquish his/her own ethnic and cultural identity. Contacts with the members of the migrants' own ethnic group are avoided and despised. In the case of assimilation there are two necessary conditions: change of the reference group and acceptance by the out-group (majority).

Separation (or segregation when this situation is imposed by other groups) means that one prefers to have contact with the larger society while maintaining one's ethnic and cultural identity. Separation entails an exclusive involvement in one's traditional cultural values and norms.

Marginalization can be characterized by a rejection and lack of involvement in one's own traditional culture, as well as the culture of the dominant society. Marginalization could be accompanied by a good deal of alienation, stress and confusion as it means losing cultural and psychological contact with both traditional culture and the culture of the host society.

Integration occurs when an individual wants to participate in both cultures and feels commitment to both. It is considered valuable to maintain one's own cultural identity as well as to adjust and become a member of the new society. Therefore, the option taken is to retain cultural identity and move to join the dominant society. In many studies (Berry 1990; Berry and Kim 1988 ) integration is related to the positive acculturation outcome, especially from the mental health viewpoint. 


\section{Historical background of Ingria and Ingrian Finns}

Geographically the traditional Ingrian area is centered around St. Petersburg and the concept "Ingrian" refers to the descendants of Finns who moved to the area in the 1600 s. In 1617 the area was transferred from Russia to Sweden in the Stolbova Peace Agreement, and it was in Sweden's interest to replace the Orthodox population with Lutherans in the area. This initiated the move of Lutheran Finns into Ingria while the Orthodox population moved east fleeing conversion. By the end of the 17 th century $90 \%$ of the population of Ingria had Finnish ancestry (De Geer 1992; Takalo and Juote 1995).

The history of Ingria was greatly changed by the Great Northern War. The area became Russian again and was officially annexed to Russia in the Uusikaupunki Peace Agreement in 1721. In 1703 Peter the Great built, by the River Neva above the Ingrian villages, a city which he called St. Petersburg after himself. The city grew rapidly and Ingria was soon absorbed into it. This new era brought with it new administrative measures and, along with other Russian influences, serfdom.

At the beginning of the 19th century Finland became a part of Russia and that also meant the beginning of a new era for Ingria. A strong national movement began in Finland at the end of the century and Finnish culture started spreading also into Ingria. The situation of the Ingrians was improved when serfdom was abolished in Russia (1861) and conditions improved generally. It may be partly due to these factors that Ingrians started, at the end of the 19th century, to be aware of their roots and a national movement began (Nevalainen 1991).

The next turning point in the history of Ingria was the Russian Revolution in 1917. In the Tartu Peace Agreement Ingrians were legally granted cultural autonomy, which never materialized. On the contrary, in addition to enforced agricultural collectivism in 1920 the first wave of deportations took place and almost 20,000 Ingrians were exiled to Siberia. In the 1930s IngrianFinnish parishes were abolished, Finnish language teaching was forbidden, and Finnish-speaking teachers and civil servants were exiled or killed. In the 1930 s a total of 50,000 Finns were exiled or deported from Ingria. They were dispersed to different parts of the Soviet Union, mostly to Siberia and Central Asia (Nevalainen 1991).

Some of the Ingrians succeeded in escaping as asylum seekers to Finland, to the young independent state, and were given refugee status. The Finnish authorities investigated the family's ability to support itself, employment, and political "credibility" when they granted refugee status. There were 8,300 Ingrians in Finland at the beginning of 1921 (Nevalainen 1991).

During the Second World War, a part of Ingria was left to Germany in the Siege of Leningrad. According to the agreement between Germany and Finland (1942) about 63,000 Ingrians were transferred to Finland. The "interim peace treaty" between the Soviet Union and Finland contained a clause which decreed that all Soviet citizens, including Ingrians, had to be returned to the Soviet Union. About 55,000 Ingrians left Finland, and although they were promised that they could go back to their homeland, the majority of them were transported directly to Siberia. The rest of these Ingrians, who decided not to return, either stayed secretly in Finland or asked for asylum mostly in Sweden (about 5,000). After the death of Stalin the Ingrians were allowed to return from exile, but according to the Soviet Russification policy, Ingria itself was forbidden for them. The Ingrians moved mostly to Soviet Karelia and later to Estonia, as well. The return of the Ingrians to Ingria was officially allowed much later, but in practice their return has been difficult due to bureaucracy, financial problems related to remigration and the fact that the population of the area had changed. (Nevalainen 1990; De Geer 1992; Takalo and Juote 1995).

During the era of "perestroika" and "glasnost" the Ingrians also experienced a new national awakening. The first Ingrian associations were founded in 1988, which did not happen without crises, personal disagreements, and conflicts of principle. The aims of the associations were the revitalization of Finnish culture and language and cooperation with other Ingrian associations abroad. Russian (then Soviet) authorities were pressured to give the Ingrians the right to return to their former homeland, political rehabilitation return of property, and support for various cultural programs. In 1993 the Russian government accepted a decree regarding the rehabilitation of Russian Finns, in other words, gave them back their historical rights and cleared them of unjust political accusations. This decree has not fulfilled the Ingrians' expectations. The Ingrian 
associations had asked for land in their historical homeland Ingria. The Russian authorities promised them 60 hectares in an area which was not what the Ingrians had hoped for. The return of land has proved problematic also in other ways. Only a few dozen people have returned so far (Kyntäjä 1997).

The Lutheran faith has always been an integral part of being an Ingrian. St. Maria's Church was completed in 1804 in St. Petersburg and the congregation was named after the church. After decades of inactivity the parish began to function again in 1970, when the first Finnish congregation in Petrozavodsk was granted permission to practice. To a larger extent the parish activities were not possible until the 1980 s as a result of Gorbachev's reforms. Today the Ingrian Church contains 30 parishes and has 15,000 members. The church is bilingual, as only about half of its middle-aged and younger members speak Finnish (Takalo and Juote 1995).

In the official census of the Soviet Union in 1989 there were 67,000 Ingrians in the country. In reality their numbers are estimated to be greater, around 80,000-100,000 (Kyntäjä 1997). The passport regulations of the former Soviet Union allowed people of 16 years of age to decide what nationality they wanted on their passports. Due to the Soviet regime and Stalin's persecutions, many people were afraid to have "Nationality: Finnish" on their passports, choosing instead, for the sake of their safety or for other reasons, Russian as their nationality. Social conditions have also played a part in the fact that the middle-aged and particularly the young Ingrians know very little about Finland and its culture and few can speak the Finnish language.

\section{Remigration policy in Finland}

The term "remigrant" as used in Finland has many different connotations, which sometimes creates misunderstanding and confusion. For a long time the concept "remigrant" has referred to those Finns who had emigrated abroad - for example to Sweden or to other Western countries - and later returned to Finland. This study focuses only on so-called ethnic remigration from the former Soviet Union. These remigrants are the descendants of the Finns, who during different periods in history migrated to the territory of the former Soviet Union. The Ingrian Finns are not the only "ethnic remigrants" from the former Soviet Union. The Ingrian Finns make up only one group of ethnic remigrants, while others are represented by the descendants of those Finns who emigrated to Russia mostly in the 1920s and 1930s, either directly from Finland or via the United States or Canada. One small group of remigrants consists of persons who emigrated to the Soviet Union after the Second World War. There is a lot of discussion of whether it is correct to make such generalizations and speak only of Ingrians in the meaning of ethnic remigrants, because there are also other remigrants from the ex-Soviet Union, who perceive themselves as Finns, not Ingrian Finns.

Remigration from the former Soviet Union to Finland started after President Koivisto's statement in 1990 when he mentioned that Ingrian Finns (and other Soviet citizens of Finnish origin) could be considered remigrants. This statement launched quite a large remigration to Finland, which is still continuing. So, the new interpretation of the concept "remigrant" refers to those who have come from the former Soviet Union to Finland after 1990 and who have been granted a residence permit and social welfare on the grounds of their Finnish origin. Among Finnish authorities and "people in the streets" the ethnic remigrants from the former Soviet union are usually called as Ingrian Finns, even though, they could never have lived in Ingria.

The criteria for getting remigrant status with different social rights were very liberal at the beginning of the 1990s. According to paragraph 1, subparagraph 1 in article 18 of the Aliens Act, which was applied to the migration of Ingrian Finns, a temporary residence permit could be granted to foreigners with a Finnish origin. A person received remigrant status, if s/he could prove that at least one of his/her grandparents were Finnish by nationality. The Finnish authorities started to prepare the reception system after the first wave of remigrants had already arrived. Fairly soon after remigration had begun, it became obvious that nearly all of the remigrants needed preparatory training like that for other immigrants. The remigration boom turned into an economic recession and massive unemployment in Finland, which made the employment 
situation for immigrants difficult (Pitkänen and Jaakkola 1997). It also turned out that the majority of Ingrian Finns who belonged to the working-age population were actually Russian speaking and their spouses and children spoke only Russian. The whole situation posed new problems for the Finnish authorities, including the need to redefine the concept and criteria for remigration.

The Parliamentary Committee on Migration and Refugee Policy was established in 1995 in order to prepare an immigrant and refugee policy for the government. The committee consisted of members of different political parties, NGOs, and leading civil servants. One of the first tasks of the committee was to make proposals to the government for redetermining the criteria for remigrant status. The Committee delivered the report on Ingrian remigration on January 30 , 1996.

The Aliens Act was amended soon after the proposals of the Parliamentary Committee on Migration and Refugee Policy were published. The amendments came into force in August 1996. This new act specified the criteria according to which residence permits should be granted for ethnic remigrants (Article 18a/511/96). The most significant change compared to previous practice is the requirement that at least two of the four grandparents must be registered as having Finnish nationality.

Finnish nationality has to be certified on the basis of the following documents:

a) A birth certificate in which both or one of the applicant's parents have been entered as Finnish by nationality.

b) In the absence of reliable documents, the applicant must prove his or her Finnish origin on the basis of one of the following original or otherwise reliable documents:

- an internal Soviet passport in which the applicant has been entered as Finnish by nationality; - a birth certificate of a close relative of the applicant, in which both or one of the parents of the close relative have been entered as Finnish by nationality;

- a marriage, divorce or adoption certificate of the applicant or his or her parents;

- a certificate issued by the National Archives of Finland;

- an official certificate issued by a Finnish parish, or some other reliable document.

The applicant must also show intent to immigrate to Finland permanently. After the Ingrian or his or her spouse have resided in Finland permanently for an uninterrupted period of two years, he or she can be granted a permanent residence permit. This requires that the applicant no longer resides permanently in the country of origin. A remigrant can apply for Finnish citizenship after five years of permanent residence in Finland. The remigrant must make the application him/herself, and no special treatment in the application process is given. In practice, remigrants have to live in Finland for six to eight years before they receive citizenship. This is mainly due to the backlog in the Immigration Office (Pitkänen and Jaakkola 1997).

Viewpoints regarding remigration of Ingrians to Finland in the traditional Ingrian area

\section{The reasons for remigration}

The members of the Ingrian Association and Church in St. Petersburg have worked with hundreds of potential remigrants and their interviews are considered expert evalutions. Based on the interviews conducted with them it is possible to say that the most common reasons for remigration are the unstable economic situation in Russia, feelings of insecurity, particularly with regard to crime, and uncertainty about the future. The seriousness of the economic situation is reflected in miserable living conditions, inadequate salaries and pensions which are not paid on time. Unemployment and the threat of becoming unemployed are also considered a real problem. The prevalence of crime and a general feeling of insecurity have made people fearful of their future. One of the most compelling reasons to move to Finland was the parents' fear for their children's future - especially fear that their sons will be drafted into the Russian army and end up fighting in a war like in Chechenya. The psychological reasons for emigration are, 
therefore, usually connected with frustration and a feeling of helplessness and also a feeling that one is not able to control one's own life. Finland is expected to provide everything that is missing in Russia. All respondents agreed that people would not be so anxious to move to Finland and leave their homes if the circumstances in Russia were different.

"... if they had a feeling of security, both psychologically and economically ... Finnish politicians would do well to calculate which is cheaper - to build houses for Ingrians here and to employ Ingrians in Finnish enterprises, for example, and thereby also benefit Finnish interests - or to pay social security for thousands of remigrants in Finland".

Paavo, 42

Remigration - what is it?

The migration of Ingrians to Finland is not, according to the respondents, remigration but emigration which results in Ingria losing its resources. In their opinion the term "remigration" should be reserved to describe the return of people from Siberia or other parts of the former Soviet Union to the historic area of Ingria. Emigration to Finland results in the population becoming more and more Russian and makes the revival of Ingrian culture and identity extremely difficult. There were three different opinions among the respondents on the question of what should be done to encourage real remigration and revival of Ingrian culture:

- According to the first opinion the Russian state owes the Ingrian people to build them their own villages in the area of historic Ingria into which the returning Ingrians from Siberia could settle.

- According to the second opinion the remigrants moving to Finland should temporarily rent out their apartments in St. Petersbug - at a reasonable price - to the Siberians who want to come back to their homeland. There are 200 Ingrian people in Siberia who would like to return, but moving is expensive and it is almost impossible to find an apartment in St. Petersburg or the surrounding area. According to this opinion, Finland should pay social benefits only for those remigrants who leave their apartments to the "real remigrants".

- The third opinion insists that it is not worth moving Ingrians from Siberia to Ingria because they have become completely Russian and they would continue becoming more and more Russian in Ingria. According to this point of view, it would be more sensible to support Finnish culture in Ingria where it already exists, in parishes, in cultural activities and so on.

\section{Target areas for Finnish support in terms of the revival of Ingrian culture and identity}

According to the people interviewed, it would be reasonable for Finland to consider increasing support to Ingrians in their homeland, rather than supporting in Finland thousands of unemployed returnees who basically do not even know the Finnish language. If Ingrians received more support at home, the pressure to move would not be so great. The following are the target areas for Finnish support from the viewpoint of the respondents:

- Culture. There are no proper cultural centers in St. Petersburg where Ingrians could meet and organize activities

- Finnish language. More should be invested in teaching Finnish. Without the Finnish language there is no Finnish identity. The main problems are the lack of professional teachers and teaching material. High-standard Finnish courses are nowadays available only for those planning to remigrate to Finland.

- Housing. Normal housing conditions in the homeland would ensure that fewer Ingrians would move to Finland. Through joint projects houses could be built in Ingria using cheap raw materials and local labor. These projects would also provide work to Finnish citizens.

- Young people and education. Education and training should be provided for young people, for example vocational training. It would be sensible to employ more Ingrian youth in 
Finnish enterprises in St. Petersburg, so that they would earn proper salaries instead of moving to Finland to join the mass of unemployed people.

- The situation of the elderly should be improved. The service house project has been valuable, but it is not enough. What is needed is an ordinary old people's home where the elderly who cannot manage alone could stay the rest of their lives.

- Joint projects. The Ingrians living in Ingria should be listened to more and their knowledge and skills should be utilized.

\section{Ethnic identity and acculturation of Ingrian remigrants in Finland}

On the basis of the conducted interviews, it could be stated that the Ingrian Finns form an especially heterogenous group in respect to their social backround and ethnic identity. The results suggest that social background, objective criteria of ethnic identity, and subjective ethnic identification of Ingrian remigrants differ remarkably between the three different age groups (generations). The Ingrian Finns could represent any large-scale citizenship of the former Soviet Union citizenships. Some still have Soviet passports. The majority have Russian or Estonian citizenship. However, citizenship - for example, Estonian citizenship - does not tell the whole story about an individual's ethnic identity. Many Russian-speaking Ingrian Finns who lived in Estonia applied for Estonian citizenship just for practical reasons - a Soviet passport was no longer valid for traveling. There are also differences in ethnic identity inside these age groups - especially among middle-aged and young Ingrians - depending on the dominant language, which is mostly Russian or Estonian.

\section{A. The elderly}

The elderly Ingrians could be defined as "real" Ingrian Finns - they were born in Ingrian families and their mother tongue is Finnish. The elderly Ingrian Finns have grown up in the historic area of Ingria during the period of the traditional Finnish village culture. Their socialization has occurred in a Finnish-speaking family and social environment. They went to Finnish schools until they were closed in the beginning of Stalin's repressions in the 1930s. Most of them were transferred to Finland during the Second World War. All respondents of this age group have been deported or prisoned and lived in exile, mostly in Siberia. This group has a strong Finnish identity, both objectively as well as subjectively. They speak fluent Finnish, they take part in the work of Lutheran parishes, they identify themselves as Ingrian Finns or just Finns and feel commitment to the Finnish culture and society. Principally they do not have acculturation problems because of their Finnish ethnic identity. Their previous minority identity has become a majority identity in Finland - they are Finns in Finland. Nevertheless - even this group has experienced prejudice from the majority. As these people still have an accent when speaking Finnish, in the eyes of the majority they are sometimes seen as Russians. These attitudes affect psychological acculturation and they cause a feeling of "mild marginalization":

"In Russia I suffered because I was a Finn, now in Finland I am considered a Russian ... but still, I am so happy to be finally in Finland and I am very grateful to the Finnish society!" Rosa, 82

The difficulties in adaptation mainly concern loneliness and the radical differences between the Soviet Union and Finnish societies. It is quite hard for old people to understand the structure of the Finnish society, the social security system, taxation, services, and all the practical things that belong to everyday life. The old Ingrian Finns almost never complain and do not easily want to bother social workers or physicians. They are afraid of one thing - that some day someone will send them back to Russia - Siberia - again. 


\section{B. The middle aged - "the lost generation"}

The middle-aged people in the research sample were born in exile during the period of Stalin's repressions, mostly in Siberia or Central-Asia. After Stalin's death their families settled mostly in Soviet Karelia and Estonia. They have heard Finnish at home from their parents in their childhood, but almost forgotten it by now. "The lost generation" could be divided into two categories. The first one involves Russian-speaking Ingrian Finns either from Russia or from Estonia. The second one involves Estonian-speaking Ingrian Finns who have come from Estonia. The majority of ethnic Finns have either a Russian (or Soviet) or Estonian identity depending on their linguistic environment during the process of socialization.

The Estonian-speaking Ingrians from Estonia identify themselves mostly as Estonians but never as Soviets. Estonian-speaking remigrants, who speak fluent Finnish language are tempted to assimilate into Finnish society. Estonians are still very vulnerable because of their past in an occupied country and the worst thing for them is to be considered Russians or Soviet. It also seems to be difficult for them to retain their cultural identity and maintain active contacts with others in Estonia as the attitudes toward Estonians who left following independence are quite negative, even hostile. Assimilation is also quite an easy strategy for Estonians to adopt given the similarity of the Finnish and Estonian language and culture. Assimilation is still very complicated for the first generation of immigrants and it also necessitates acceptance by the host society.

"The lost generation" involves one interesting subgroup - Russian-speaking Ingrian Finns from Estonia. They have assimilated into the Russian population in Estonia and identify themselves mostly as Soviet people. The remigrants from this group have never learned Estonian and in Finland after three or four years of residence they are not able to communicate in Finnish. These middle-aged Russian-speaking remigrants are mostly unemployed, their social network is limited to contacts with other Russian-speaking remigrants, and they have strong doubts about their ethnic identity:

“... well, I am an Ingrian remigrant ... but I don't speak Finnish; I probably still consider myself as Russian or ... we were actually Soviet people, it was not important what nationality you belonged to ... After Estonia got it's independence everything changed ... we became immigrants and we were supposed to learn Estonian ..."

\section{Sergei, 52}

Generally Russian-speaking middle-aged remigrants had the most serious difficulties in integrating into the Finnish society. There are different reasons for this: 1) they usually do not speak Finnish, 2) they are mostly unemployed, 3) Russian culture and its way of life (and the heritage of the Soviet system) is different from the Finnish and 4) there are negative prejudices towards Russians in Finland. On the basis of the results, it would seem that Russian-speaking middle-aged remigrants can be classified according to both the marginalization and the separation option within Berry's theory of psychological acculturation. These marginalized people, who do not know where they belong and who they are, are commited to each other and to making their own subculture that is separate from the Finnish culture.

"I have started to suspect my dignity. I worked in a Finnish enterprise as an expert and I felt good. I was ashamed of my "countrymen" who just took money from the social security office for doing nothing. Now I am unemployed and I feel that I don't belong to the Finnish society anymore; I just sit around all day with my countrymen playing cards ... They are committed to me now ... I have thought about suicide ..."

Valeri, 48

Basically the Russian-speaking and Estonian-speaking middle-aged remigrants had the same acculturation problems. "The lost generation" experienced problems of unemployment, loneliness, and identity conflict. According to Berry's acculturation model this age group is extremely separated into its own group. They also feel that they are subjected to stereotypes and xenophobia by Finns. Even those who have integrated, to some degree, into Finnish society - speak Finnish fluently, who have good jobs, have Finnish friends, etc., - feel a lack of confidence and a sense of being a foreigner. They still feel uncomfortable because they feel that Finns insist on classifying them on the basis of their Eastern European or communist origins. 


\section{The young remigrants - "Russian or Estonian immigrants"}

The third group can be characterized by a large age scale, but the social backround is basically the same. All respondents in this group have one parent of Finnish origin (Ingrian Finn) and the other either Russian or Estonian. They were born and socialized either in Russia or Estonia and their ethnic self-identification did not involve a Finnish component. Contact with the Finnish culture and language has been minimal or it has been missing entirely. The respondents said in the interviews that they were not even aware of their Finnish roots before moving to Finland.

Acculturation is the most risky for these young adults, who have no profession and whose studies are not finished. Because they do not speak Finnish it is almost impossible to find a job. All respondents had serious difficulties at school and in making friends. They did not know what to answer to the questions concerning their remigrant status and the fact that they did not speak Finnish correctly. They feel different from the others and this leads to alienation and confusion. This generation also has misunderstandings and conflicts with their parents, who are not able to support them because they have troubles of their own. In respect to the acculturation theory, this contingent can be characterized by the mode of separation with some elements of marginalization.

There also exists a so-called elite group with good education, who are working or studying in Finland. According to Berry's theory these persons usually have no serious integration problems. They are able to participate in both cultures and develop an ability to straddle both traditions after four or five years in Finland. The option of integration requires good self-esteem and an ability to cope with stress. These young "remigrants" face the same circumstances as "ordinary" immigrants and, considering their objective and subjective identity, could be classified as immigrants.

There is a very interesting research result that refers to the new phenomenon regarding the relationships between Russian-speaking and Estonian speaking young remigrants. They have recently grown closer and made friends with one another, especially with the opposite sex. These young remigrants have common experiences with the hostile attitudes of the host population and these similar experiences seem to bring "old enemies" together.

\section{Conclusions}

The Ingrian remigrant population is very heterogenous in terms of their ethnic identity. Among the returnees of the 1990s three different age groups (generations) of Ingrian Finns can be identified. The older Finnish-speaking people, "the real Ingrian remigrants", who were in Finland during the Second World War, have a strong (Ingrian) Finnish identity and they do not have problems concerning ethnic self-identification except in sometimes being treated and considered as Russians. The middle-aged remigrants from the "lost generation" have experienced serious acculturation difficulties in respect to cultural shock, the differences in the structure of society, negative attitudes of the host society, the problems of not knowing the language, loneliness, and last but not the least, the high unemployment in Finland. Especially the Russianspeaking middle-aged remigrants are forming their own subculture of marginalized people, who are committed to each other. Within Berry's theory of psychological acculturation the "lost generation" is both marginalized and separated from the host society. The younger generation of remigrants represent the Russian and Estonian population as ordinary immigrants and are moving closer to each other. Young remigrants do not feel-commitment to the Finns and their social networks develop mostly within their own group referring to a separation mode.

The majority of the Russian- and Estonian-speaking remigrant population in Finland lives in certain urban areas, mostly in multidwelling districts, so called low-status suburbs. As this group lives predominantly on social welfare and has few contacts with the Finnish population, there is a tendency to develop a new subculture which is totally separate from the Finnish 
society. The active "remigration" from Russia and Estonia is reflected in the growth of the foreign population in Finland, posing new problems to the Finnish authorities. One problem concerns ethnic segregation within urban districts - will there be so-called ghettos, where the majority of the residents are unemployed and socially disadvantaged Finns and migrants, as has happened in other European countries? There already is growing evidence of such a phenomenon in some of Finland's larger cities.

\section{Acknowledgements}

The author wishes to thank the Alli Paasikivi Foundation for financial support of this project.

\section{References}

Berry, J.W. 1990. Psychology of acculturation: understanding individuals moving between cultures. In: Applied cross-cultural psychology, edited by R.W. Brislin. London: Sage.

Berry, J.W. 1992. Acculturation and adaptation in a new society. International Migration 30(1):69-85.

Berry, J.W. and U. Kim. 1988. Acculturation and mental health. In: Health and cross-cultural psychology, edited by P. Dasen and N. Sartorius, pp. 207-236. London: Sage.

De Geer, E.1992. The Finns from Ingermanland: some notes on the ethnic group's historical past, on the mapping of its present locations and about its future. Uppsala: Uppsala Universitet.

Dijk, Teun A. van. 1989. Communicating racism: ethnic prejudice in thought and talk. London: Sage.

Hutnik, N. 1991. Ethnic minority identity: a social psychological perspective. Oxford: Clarendon Press.

Jaakkola, M. 1995. Suomalaisten kiristyvät ulkomaalaisasenteet (The attitudes of the Finns towards foreigners are getting stricter). Työpolittinen tutkimus 101. Helsinki: Työministeriö.

Kyntäjä, E. 1997. The remigration of Ingrians to Finland - remigration or emigration? In: Ingrians in municipalities, edited by M. Pitkänen and A. Jaakkola. Helsinki: The Association of Finnish Local Authorities.

Liebkind, K. 1989. Conceptual approaches to ethnic identity. In: New identities in Europe, immigrant ancestry and the ethnic identity of youth, edited by K. Liebkind. Aldershot: Gower Press

Liebkind, K. 1992. Ethnic identity - challenging the boundaries of social psychology. In: Social psychology of identity and self concept, edited by G. Breakwell. Surrey: Surrey University Press.

Liebkind, K. 1996. Acculturation and stress: Vietnamese refugees in Finland. Journal of Cross Cultural Psychology 27(2):161-180.

Maahanmuutto- ja pakolaisuuspoliittinen toimikunta. 1996. Inkeriläisten paluumuuttoa koskeva selvitys (Report on the remigration of Ingrians). Sisäministeriön julkaisu. Helsinki: Sisäasiainministeriö.

Maahanmuutto- ja pakolaisuuspoliittinen toimikunta. 1997. Hallittu maahanmuutto ja tehokas kotoutuminen: ehdotus hallituksen maahanmutto- ja pakolaispoliittiseksi ohjelmaksi (Controlled immigration and effective acculturation: a proposal for immigration and refugee political program of the Government). Sisäministeriön julkaisu 1/1997. Helsinki.

Nevalainen, P. 1991. Inkerinmaan ja inkeriläisten vaiheet 1900-luvulla. In: Inkerin historia, kansa, kulttuuri (The history, people, and culture of Ingria), edited by H. Nevalainen and H. Sihvo. Helsinki: Suomalaisen kirjallisuuden seura.

Phinney, J.S. 1990. Ethnic identity in adolescents and adults. Review of Research. Psychological Bulletin (38) 3:449-514.

Pitkänen, M. and A. Jaakkola. 1997. Ingrians in municipalities. Helsinki: The Association of Finnish Local Authorities.

Söderling, I. 1997. Maahanmuuttoasenteet ja elämänhallinta (Attitudes towards immigration and life management). Väestöntutkimuslaitoksen julkaisusarja D 30. Helsinki: Väestöntutkimuslaitos, Väestöliitto.

Takalo, P. and M. Juote. 1995. Inkerinsuomalaiset (Ingrian Finns). Helsinki: Sosiaali- ja terveysministeriö. Pakolaistoimisto.

Weinreich, P. 1989. Conflicted identifications: a commentary on identity structure analysis concepts. In: New identities in Europe, immigrant ancestry and the ethnic identity of youth, edited by K. Liebkind. Aldershot: Gower Press. 